June 1989

\title{
Book Review: Humanizing Freud
}

\author{
Edward Kim, M.D. \\ Thomas Jefferson University, Philadelphia, PA
}

Follow this and additional works at: https://jdc.jefferson.edu/jeffjpsychiatry

Part of the Psychiatry Commons

Let us know how access to this document benefits you

\section{Recommended Citation}

Kim, M.D., Edward (1989) "Book Review: Humanizing Freud," Jefferson Journal of Psychiatry. Vol. 7 : Iss. 2 , Article 16.

DOI: https://doi.org/10.29046/JJP.007.2.015

Available at: https://jdc.jefferson.edu/jeffjpsychiatry/vol7/iss2/16

This Article is brought to you for free and open access by the Jefferson Digital Commons. The Jefferson Digital Commons is a service of Thomas Jefferson University's Center for Teaching and Learning (CTL). The Commons is a showcase for Jefferson books and journals, peer-reviewed scholarly publications, unique historical collections from the University archives, and teaching tools. The Jefferson Digital Commons allows researchers and interested readers anywhere in the world to learn about and keep up to date with Jefferson scholarship. This article has been accepted for inclusion in Jefferson Journal of Psychiatry by an authorized administrator of the Jefferson Digital Commons. For more information, please contact: JeffersonDigitalCommons@jefferson.edu. 


\title{
Humanizing Freud
}

\author{
FREUD: A LIFE FOR OUR TIME \\ Peter Gay, Ph.D. \\ W.W. Norton \& Company \\ New York, 1988 \\ 651 pages \\ $\$ 25.00$
}

\section{Edward Kim, M.D.}

Peter Gay's Freud: A Life for Our Time reads like an epic novel. This might cause some to feel that the author is somehow cheapening his subject, rendering it digestible to a generation raised on Harold Robbins and "General Hospital." Nevertheless, I thoroughly enjoyed the book. Far from trivializing the life and work of one of this century's most influential thinkers, Gay has succeeded admirably in humanizing a Freud who has alternately been maligned and mythologized but rarely accessible.

A nonmedical cultural historian with formal psychoanalytic training, Dr. Gay possesses a literary style which gives his subject matter a vibrant tangibility, making his work a pleasure to read. In particular, his ability to deftly weave cultural and political factors into the text provides a complex and tumultuous stage for this fascinating drama, a story worth reading. Freud is depicted as a devoted husband, loving father, and beleagured founder of psychoanalysis, but Dr. Gay never lets us lose sight of the entire man, a complex character at once intimidating and approachable. The young Sigmund who refused to play the meek "good Jew" to his Gentile classmates at the University of Vienna is every bit the forerunner of "Herr Professor," the indomitable and prolific mind behind the psychoanalytic movement. The work's chief strength, however, lies in its depiction of Freud as a man of relationships rather than merely a lone explorer. The tension and passion of his life is highlighted through correspondences with Wilhelm Fliess, C.G. Jung, Sandor Ferenczi, and Lou AndreasSalome. Gay sensitively outlines recurrent themes in Freud's life as they were influenced by powerful relationships: his own oedipal conflicts affecting (perhaps inhibiting) his exploration of female psychology; his penchant for fostering ill-fated relationships with adherents who ultimately "betrayed" him. By casting Freud in the context of his most important relationships, Peter Gay reveals the man behind the work, an utterly human, courageously vulnerable scholar and clinician. 
One aspect of the book which I initially found annoying is Gay's use of a topical rather than purely chronological structure. The individual chapters are grouped into sections representing historical epochs in Freud's life: the pre-and proto-psychoanalytic period of 1856-1905; the elaborations of 1902-1915; the revisions of 1915-1939. However, each chapter discusses a particular issue or theme affecting Freud and psychoanalysis. Moreover, chapters are subdivided into still more discreet topics, some of which may take place concurrently with one another and even with events in different chapters. This frustrated my obsessive desire for order, but I was compensated by a multilayered appreciation of the complexity and richness of Freud's life. A quick rereading and crossreferencing of confusing sections helped bring the temporal aspects into greater relief. Dr. Gay has clearly written a biography rather than a chronology. We come to understand Freud as an individual who lived much more than a series of historical events and papers. Such is the value of good biography.

The very phrase, "A Life for Our Time," indicates that the author has attempted to interpret the Freud of late Victorian Europe to an entirely different world. In the end, each of us will construct our own Freud based on our personalities and the available data. Dr. Gay has given us a Freud biography which emphasizes his struggles and triumphs against the backdrop of human weakness and historical change. In a world weary of media-marketed politicians and unblemished heroes, Peter Gay's biography portrays a life we can appreciate in our time. 